\title{
EVALUASI TERHADAP PENYALURAN, PENGELOLAAN DAN PERTANGGUNGJAWABAN PENGGUNAAN DANA DESA DALAM MENINGKATKAN KESEJAHTERAAN MASYARAKAT DESA PADA PEMERINTAH DAERAH KABUPATEN BINTAN
}

\author{
Salihi \\ Dosen STIE Pembangunan \\ E-mail : salihi@stie-pembangunan.ac.id
}

\begin{abstract}
Abstrak : Penelitian ini bertujuan untuk membandingkan mekanisme distribusi, pengelolaan dan pertanggungjawaban penggunaan dana desa di Pemerintah Kabupaten Bintan dengan ketentuan dan peraturan yang berlaku. Metode yang digunakan dalam penelitian ini adalah metode deskriptif kualitatif dengan melakukan pengumpulan data melalui observasi, studi literatur dan wawancara dengan pihak yang berwenang. Dana Desa adalah dana yang dikeluarkan oleh Pemerintah Pusat untuk membantu mempercepat pembangunan di desa-desa, membantu meningkatkan ekonomi di desa-desa dan juga membantu biaya operasional administrasi desa untuk memaksimalkan layanan maksimum bagi penduduk desa.

Peraturan Menteri Keuangan No. 93 / PMK.07 / 2015 telah dengan jelas menetapkan prosedur untuk alokasi, distribusi, penggunaan, pemantauan dan evaluasi dana desa. Oleh karena itu, pejabat pemerintah desa diwajibkan untuk sepenuhnya memahami peraturan yang berlaku untuk mengelola, menggunakan, dan menghitung dana desa secara maksimal, benar, dan bertanggung jawab. Akuntabilitas pengeluaran mutlak dalam penggunaan dana desa sebagai bentuk administrasi dan akuntabel secara moral. Untuk itu setiap aparatur Negara yang menggunakan anggaran Negara harus bertanggung jawab dan bertanggung jawab.
\end{abstract}

Kata Kunci : Dana Desa, Penyaluran, Manajemen, Akuntabilitas, Meningkatkan Kesejahteraan

Abstract : This study aims to compare the mechanism of distribution, management and accountability of the use of village funds in the Government of Bintan Regency with the rules and regulations applicable. The method used in this research is descriptive qualitative method by conducting data collection through observation, literature study and interview with the authorized party. Village Funds are funds disbursed by the Central Government to help accelerate development in the villages, help improve the economy in the villages and also help the operational costs of village administration in order to maximize the maximum service for the villagers.

Regulation of the Minister of Finance No. 93 / PMK.07 / 2015 has clearly set out procedures for the allocation, distribution, use, monitoring and evaluation of village funds. Therefore, village government officials are required to fully understand the prevailing regulations in order to manage, use and account for village funds maximally, correctly and accountable. Expenditure accountability is absolute in the use of village funds as a form of administrative and morally accountable. For that every State apparatus using State budget must be accountable properly and accountable.

Key Words : Village Funding, Channeling, Management, Accountability, Improving Prosperity 
Berdasarkan Undang-Undang Nomor 6 Tahun 2014 tentang Desa, Desa mempunyai sumber pendapatan berupa pendapatan asli daerah, bagi hasil pajak daerah dan retribusi daerah kabupaten/ kota, bagian dari dana perimbangan keuangan pusat dan daerah yang diterima oleh kabupaten/ kota, alokasi anggaran dari APBN, bantuan keuangan dari APBD propinsi dan APBD Kabupaten/ Kota, serta hibah dan sumbangan yang tidak mengikat dari pihak ketiga.

Sumber pendapatan Desa tersebut secara keseluruhan digunakan untuk mendanai seluruh kewenangan yang menjadi tanggungjawab Desa. Dana tersebut digunakan untuk mendanai penyelenggaraan kewenangan Desa yang mencakup penyelenggaraan pemerintahan, pembangunan, pemberdayaan masyarakat, dan kemasyarakatan. Dengan demikian pendapatan Desa yang bersumber dari APBN juga digunakan untuk mendanai kewenangan tersebut.

Berdasarkan Undang-Undang Nomor 6 Tahun 2014 tentang Desa, Desa diberikan kewenangan untuk mengatur dan mengurus kewenangannya sesuai dengan kebutuhan dan prioritas Desa. Hal itu berarti Dana Desa akan digunakan untuk mendanai keseluruhan kewenangan Desa sesuai dengan kebutuhan dan prioritas Desa tersebut. Namun, mengingat Dana Desa bersumber dari Belanja Pusat, untuk mengoptimalkan penggunaan Dana Desa, Pemerintah diberikan kewenangan untuk menetapkan prioritas penggunaan Dana Desa untuk mendukung program pembangunan Desa dan pemberdayaan masyarakat desa. Penetapan prioritas penggunaan Dana Desa tersebut tetap sejalan dengan kewenangan yang menjadi tanggungjawab Desa.

Menurut Peraturan Pemerintah Republik Indonesia Nomor 60 Tahun 2014 Tentang Dana Desa yang bersumber dari Anggaran Pendapatan dan Belanja Negara, Alokasi anggaran untuk Dana Desa ditetapkan sebesar 10\% (sepuluh per seratus) dari Total Dana transfer ke Daerah dan akan dipenuhi secara bertahap sesuai dengan kemampuan APBN. Dalam masa transisi, sebelum Dana Desa mencapai 10\% (sepuluh per seratus), anggaran Dana Desa dipenuhi melalui realokasi dari Belanja Pusat dari program yang berbasis Desa.Kementerian/ lembaga mengajukan anggaran untuk program yang berbasis Desa kepada Menteri untuk ditetapkan sebagai sumber Dana Desa.

Dalam hal Dana Desa telah dipenuhi sebesar 10\% (sepuluh per seratus) dari total Dana Transfer ke Daerah, penganggaran sepenuhnya mengikuti mekanisme penganggaran dana Bendahara umum Negara yang sudah diatur sesuai dengan ketentuan perundang-undangan.

Sumber Dana Desa yang diusulkan oleh kementerian/ lembaga dan yang ditetapkan oleh Menteri akan ditempatkan sebagai belanja pusat Non Kementerian/ Lembaga sebagai cadangan Dana Desa. Cadangan Dana Desa tersebut diusulkan oleh 
pemerintah dalam rangka pembahasan rancangan APBN dan Rancangan Undangundang APBN.

Cadangan Dana Desa yang telah mendapat persetujuan dari Dewan Perwakilan Rakyat akan ditetapkan sebagai Dana Desa yang merupakan bagian dari Anggaran Transfer ke Daerah dan Desa. Mekanisme tersebut ditempuh agar pemenuhan Dana Desa tetap terlihat adanya pengalihan belanja pusat ke Dana Desa berupa Dana transfer ke Daerah. Selain itu, mekanisme tersebut juga memberikan komitmen kuat kepada Pemerintah dan Dewan Perwakilan Rakyat untuk memberdayakan Desa.

Peraturan Pemerintah Republik Indonesia Nomor 60 Tahun 2014 mengamanahkan bahwa besaran Dana Desa yang telah ditetapkan dalam APBN dialokasikan ke Desa dalam 2 (dua) tahap :

1. Pada tahap pertama, menteri mengalokasikan Dana Desa kepada Kabupaten/ Kota sesuai dengan jumlah desa berdasarkan variable jumlah penduduk, luas wilayah, dan angka kemiskinan dalam bobot tertentu. Hasil perhitungan tersebut selanjutnya dikalikan dengan indeks kemahalan konstruksi sebagai indikator yang mencerminkan tingkat kesulitan geografis.

2. Pada tahap kedua, berdasarkan besaran Dana Desa setiap Kabupaten/ Kota, Bupati/ Walikota mengalokasikan Dana
Desa kepada setiap Desa. Bupati/ Walikota diberikan kewenangan untuk menentukan bobot variable tingkat kesulitan geografis desa sebagai salah satu variable perhitungan sesuai dengan karakteristik daerahnya. Tingkat kesulitan geografis antara lain ditunjukkan oleh faktor ketersediaan pelayanan dasar serta kondisi infrastruktur dan transportasi.

Berdasarkan latar belakang yang telah dikemukakan di atas, maka identifikasi masalah dalam penelitian ini, antara lain:

1. Bagaimana Mekanisme Penyaluran Dana Desa di Desa Berakit Kecamatan Teluk Sebong Kabupaten Bintan?

2. Bagaimana Pengelolaan Dana Desa di Desa Berakit Kecamatan Teluk Sebong Kabupaten Bintan?

3. Bagaimana Pertanggungjawaban Penggunaan Dana Desa di Desa Berakit Kecamatan Teluk Sebong Kabupaten Bintan?

Definisi Operasional merupakan proses penguraian penelitian kedalam subvariabel, dimensi, indikator subvariabel, dan pengukuran. Menurut Sularso (2005:17) variabel adalah sesuatu yang memiliki nilai. Nilai bias berbeda pada saat yang berbeda untuk obyek atau orang yang sama. Nilai juga dapat berbeda pada saat yang sama untuk berbeda obyek atau orang.

\section{Mekanisme Penyaluran Dana Desa}

Mekanisme menurut kamus Besar Bahasa Indonesia Online (2016:1) adalah cara 
kerja suatu organisasi (perkumpulan dan sebagainya). Menurut Wikipedia Ensiklopedia (2014:1), Mekanisme berasal dari kata dalam bahasa Yunani mechane yang memiliki arti instrumen, mesin pengangkat beban, perangkat, peralatan untu membuat sesuatu dan dari kata mechos yang memiliki arti sarana dan cara menjalankan sesuatu. Mekanisme dapat diartikan dalam banyak pengertian yang dapat dijelaskan menjadi 4 pengertian. Pertama, mekanisme adalah pandangan bahwa interaksi bagian-bagian dengan bagian-bagian lainnya dalam suatu keseluruhan atau sistem secara tanpa disengaja menghasilkan kegiatan atau fungsi-fungsi sesuai dengan tujuan. Kedua, mekanisme adalah teori bahwa semua gejala dapat dijelaskan dengan prinsip-prinsip yang dapat digunakan untuk menjelaskan mesin-mesin tanpa bantuan inteligensi sebagai suatu sebab atau prinsip kerja. Ketiga, mekanisme adalah teori bahwa semua gejala alam bersifat fisik dan dapat dijelaskan dalam kaitan dengan perubahan material atau materi yang bergerak. Keempat, mekanisme adalah upaya memberikan penjelasan mekanis yakni dengan gerak setempat dari bagian yang secara intrinsik tidak dapat berubah

\section{Penggunaan Dana Desa}

Pasal 21 PMK Nomor 93 (2015:7) menjelaskan Dana Desa digunakan untuk
1. membiayai penyelenggaraan pemerintahan

2. membiayai pembangunan desa

3. pemberdayaan masyarakat

4. kegiatan kemasyarakatan.

Menteri Desa, Pembangunan Daerah Tertinggal dan Transmigrasi menetapkan Prioritas penggunaan Dana Desa adalah untuk membiayai pembangunan dan pemberdayaan masyarakat yang dilengkapi dengan pedoman umum pelaksanaan penggunaan Dana Desa dan pedoman teknis yang diterbitkan oleh Bupati/ Walikota.

Pada Pasal 23 PMK Nomor 93 (2015:12) juga menetapkan bahwa Dana Desa juga dapat digunakan untuk membiayai kegiatan yang tidak termasuk dalam prioritas penggunaan Dana Desa, namun harus mendapatkan persetujuan dari Bupati/ Walikota yang diberikan pada saat evaluasi rancangan peraturan Desa mengenai Anggaran Pendapatan dan Belanja Desa. Dalam hal memberikan persetujuan untuk penggunaan Dana Desa yang tidak termasuk dalam kegiatan prioritas ini, Bupati/ Walikota harus memastikan pengalokasian Dana Desa untuk kegiatan prioritas telah terpenuhi dan/ atau kegiatan pembangunan dan pemberdayaan masyarakat telah terpenuhi.

Adapun konsep evaluasi penggunaan dana desa adalah 
1. Masih terdapat penggunaan Dana Desa di luar prioritas penggunaan

2. Pekerjaan konstruksi dilakukan seluruhnya oleh Pihak Ketiga

3. Hasil pengadaan tidak dapat digunakan/dimanfaatkan;

4. Pengeluaran Dana Desa tidak didukung dengan bukti

\section{Pertanggungjawaban Dana Desa}

Abdul Halim (2007:35) menjelaskan pengertian pertanggungjawaban menurut akuntansi pemerintahan adalah, memberikan informasi keuangan yang lengkap, cermat, dalam bentuk dan waktu yang tepat yang berguna bagi pihak yang bertanggungjawab terhadap operasi unitunit pemerintahan. Sedangkan pengertian Pertanggungjawaban dari sisi Akuntansi menurut Yayah Pudin Shatu (2016:111) yaitu Akuntansi Pertanggungjawaban merupakan suatu sistem akuntansi yang disusun sedemikian rupa sehingga informasi yang dihasilkan menunjukkan tingkat kegiatan yang dikaitkan dengan tanggungjawab orang atau bagian tertentu. Pengertian pertanggungjawaban menurut Agn. Supriyanto (2015:63) dalam ruang lingkup perkoperasian adalah, Keharusan seseorang untuk menjawab atau menjelaskan hasil kerjanya.

\section{HASIL DAN PEMBAHASAN}

Dana Desa adalah dana yang bersumber dari Anggaran Pendapatan dan
Belanja Negara yang diperuntukkan bagi sebuah Desa ditransfer melalui Anggaran Pendapatan dan Belanja Daerah kabupaten/kota dan digunakan untuk membiayai penyelenggara pemerintahan, pembangunan, serta pemberdayaan masyarakat, dan kemasyarakatan. Fokus penting dari penyaluran dana ini lebih terkait pada implementasi pengalokasian Dana Desa agar bisa sesempurna gagasan para inisiatornya. Skenario awal Dana Desa ini diberikan dengan mengganti program pemerintah yang dulunya disebut PNPM, namun dengan berlakunya Dana Desa ini, dapat menutup kesempatan beberapa pihak asing untuk menyalurkan dana ke daerah di Indonesia dengan -program yang sebenarnya juga dapat menjadi pemicu pembangunan daerah.

Sesuai dengan amanat Undang-Undang Nomor 6 Tahun 2014 tentang Desa, Pemerintah mengalokasikan Dana Desa, melalui mekanisme transfer kepada Kabupaten/Kota. Berdasarkan alokasi Dana tersebut, maka tiap Kabupaten/Kota mengalokasikannya ke pada setiap desa berdasarkan jumlah desa dengan memperhatikan jumlah penduduk (30\%), luas wilayah (20\%), dan angka kemiskinan (50\%). Hasil perhitungan tersebut disesuaikan juga dengan tingkat kesulitan geografis masing-masing desa. Alokasi anggaran sebagaimana dimaksud di atas, bersumber dari Belanja Pusat dengan mengefektifkan program yang berbasis Desa 
secara merata dan berkeadilan. Besaran alokasi anggaran yang peruntukannya langsung ke Desa ditentukan 10\% (sepuluh perseratus) dari dan di luar dana Transfer Daerah (on top) secara bertahap.

Berdasarkan Peraturan Pemerintah No. 60 Tahun 2014 tentang Dana Desa Yang Bersumber dari APBN, dengan luasnya lingkup kewenangan Desa dan dalam rangka mengoptimalkan penggunaan Dana Desa, maka penggunaan Dana Desa diprioritaskan untuk membiayai pembangunan dan pemberdayaan masyarakat Desa. Penetapan prioritas penggunaan dana tersebut tetap sejalan dengan kewenangan yang menjadi tanggungjawab Desa. Sedangkan untuk Kabupaten Bintan pada Tahun Anggaran 2015 dialokasikan sebesar Rp.24.783.000.000,- dan pada Tahun anggaran 2016 mendapat alokasi sebesar Rp.62.743.156.399,-. Dan pada tahun 2017 sebesar 72.695.470.399,-

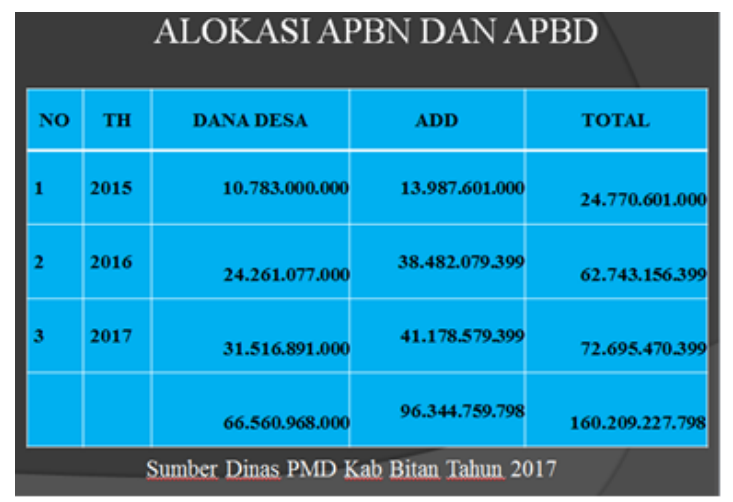

sampai dengan tahun 2016 proporsi penggungaan dana desa di Kabupaten Bintan masih didominasi bidang pembangnan sebesar $85 \%$ ini digunakan untuk pembangunan infrastruktur pedesaan seperti, jalan desa, sarana olah raga, posyandu, dan lain lain. Sedangkan yang $3 \%$ digunakan untuk pembinaan , $11 \%$ untuk pemberdayaan dan $1 \%$ digunakan untuk pemerintahan . untuk lebih jelasnya dapat dilahat pada gambar berikut :

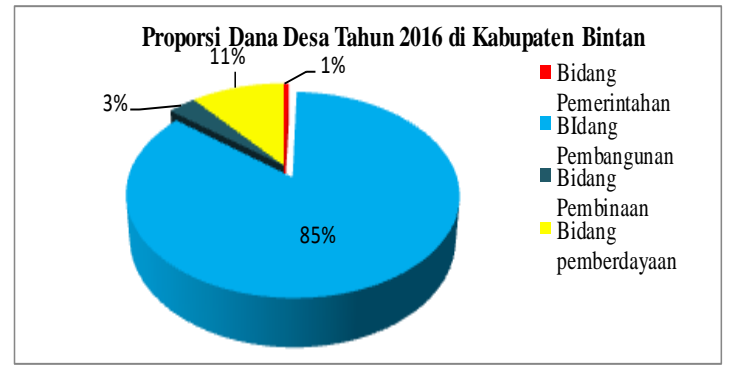

Dari hasil wawancara dengan Kepala Bidang Anggaran Dinas Pendapatan dan Pengelolaan Keuangan Daerah Kabupaten Bintan dan dari data laporan realisasi anggaran dana untuk desa berakit serta dari hasil penelitian penulis dengan wawancara kepala desa berakit bapak Muhammad Adnan didapatkan informasi bahwa dana yang dianggarkan untuk desa berakit kabupaten Bintan ada tiga jenis anggaran yaitu :

\section{Dana Alokasi Khusus Desa/ Kelurahan}

Yaitu dana yang diperuntukan untuk setiap desa di Kabupaten Bintan yang dapat dipergunakan untuk sarana dan prasarana fisik atau bangunan. Dana ini bersumber dari Angaran Pendapatan dan Belanja Daerah Kabupaten Bintan dan atau Dana Perimbangan APBD Provinsi yang dialokasikan kepada desa atau kelurahan tertentu dengan tujuan untuk membantu pendanaan kegiatan khusus 
yang merupakan bagian dari prioritas dan urusan daerah.

Sesuai dengan peruntukannya dana alokasi khusus desa/ kelurahan digunakan untuk semesisasi, paving block, pengerasan jalan, batu miring, bahu jalan, tambatan perahu, drainase, sarana air bersih desa dan MCK, bangunan sederhana seperti PAUD, TPQ dan tempat ibadah, dalin lain-lain yang disepakati bersama mempunyai nilai tambah bagi pembangunan desa/ kelurahan

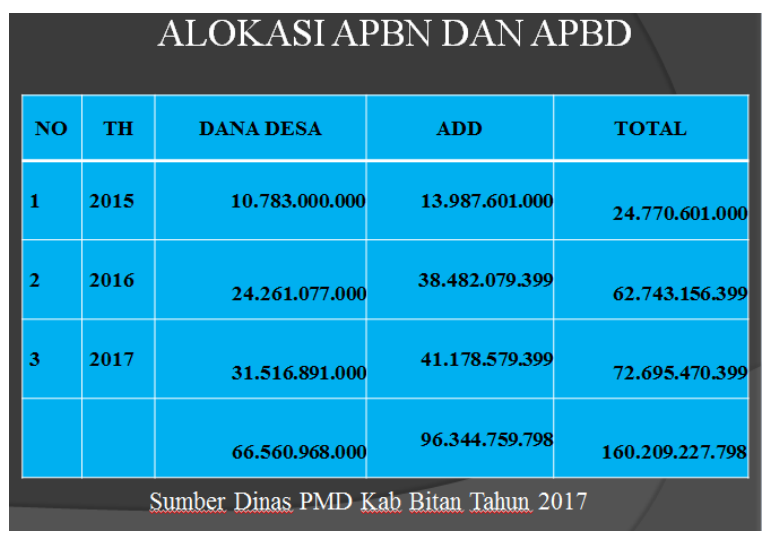

Pagu dan Realisasi Penggunaan Dana

Alokasi Khusus Desa

\begin{tabular}{|c|c|c|c|c|}
\hline $\begin{array}{c}\text { TAH } \\
\text { UN }\end{array}$ & PAGU & $\begin{array}{c}\text { REALIS } \\
\text { ASI }\end{array}$ & $\begin{array}{c}\text { PERSEN } \\
\text { TASE }\end{array}$ & $\begin{array}{c}\text { SUM } \\
\text { BER }\end{array}$ \\
\hline 2012 & $\begin{array}{c}19.267 .9 \\
37.846\end{array}$ & $\begin{array}{c}13.842 .9 \\
48.220\end{array}$ & 71,84 & $\begin{array}{c}\text { DAK- } \\
\text { DES }\end{array}$ \\
\hline 2013 & $\begin{array}{c}13.985 .9 \\
78.328\end{array}$ & $\begin{array}{c}1.498 .66 \\
0.397\end{array}$ & 10,72 & $\begin{array}{c}\text { DAK- } \\
\text { DES }\end{array}$ \\
\hline 2014 & $\begin{array}{c}4.958 .51 \\
5.000\end{array}$ & $\begin{array}{c}4.958 .51 \\
5.000\end{array}$ & 100,00 & $\begin{array}{c}\text { DAK- } \\
\text { DES }\end{array}$ \\
\hline 2015 & $\begin{array}{c}9.105 .00 \\
0.000\end{array}$ & $\begin{array}{c}8.854 .60 \\
0.000\end{array}$ & 97,25 & $\begin{array}{c}\text { DAK- } \\
\text { DES }\end{array}$ \\
\hline 2016 & $\begin{array}{c}2.276 .50 \\
0.000\end{array}$ & $\begin{array}{c}2.276 .50 \\
0.000\end{array}$ & 100,00 & $\begin{array}{c}\text { DAK- } \\
\text { DES }\end{array}$ \\
\hline
\end{tabular}

Sumber : LKP Kabupaten Bintan

\section{Dana Alokasi Umum Desa}

Dana Alokasi Umum Desa adalah Dana yang dialokasikan oleh pemerintah kabupaten untuk desa, yang bersumber dari bagian dana perimbangan keuangan pusat dan propinsi yang diterima oleh kabupaten untuk desa. Dari hasi wawancara Dana Alokasi Umum Desa yang ada di desa berakit digunakan untuk membiayai :

1) Belanja Aparatur dan biaya operasional Pemerintahan Desa

2) Belanja pemberdayaan masyarakat seperti :

a. biaya perbaikan sarana publik dalam skala kecil

b. penyertaan modal usaha masyarakat melalui BUMDes

c. perbaikan lingkungan dan pemukiman

d. perbaikan kesehatan dan pendidikan

e. peningkatan ketahanan pangan

f. peningkatan kesejahteraan masyarakat desa

Tabel.2

Pagu dan Realisasi Dana Alokasi Umum Desa

\begin{tabular}{|c|c|c|c|c|}
\hline TAHUN & PAGU & REALISASI & $\begin{array}{c}\text { PERSEN } \\
\text { TASE }\end{array}$ & $\begin{array}{l}\text { SUM } \\
\text { BER }\end{array}$ \\
\hline 2012 & $\begin{array}{c}7.809 .880 . \\
090\end{array}$ & $\begin{array}{c}8.418 .350 . \\
128\end{array}$ & 107,79 & $\begin{array}{l}\text { DAU } \\
\text {-DES }\end{array}$ \\
\hline 2013 & $\begin{array}{c}11.000 .000 . \\
000\end{array}$ & $\begin{array}{c}5.045 .705 . \\
520\end{array}$ & 45,87 & $\begin{array}{c}\text { DAU } \\
\text {-DES }\end{array}$ \\
\hline 2014 & $\begin{array}{c}12.091 .160 . \\
004\end{array}$ & $\begin{array}{c}12.091 .160 . \\
004\end{array}$ & 100,00 & $\begin{array}{c}\text { DAU } \\
\text {-DES }\end{array}$ \\
\hline 2015 & $\begin{array}{c}13.736 .479 . \\
304\end{array}$ & $\begin{array}{c}13.736 .479 . \\
304\end{array}$ & 100,00 & $\begin{array}{c}\text { DAU } \\
\text {-DES }\end{array}$ \\
\hline 2016 & $\begin{array}{c}14.606 .703 . \\
000\end{array}$ & $\begin{array}{c}14.384 .657 . \\
676\end{array}$ & 98,48 & $\begin{array}{c}\text { DAU } \\
\text {-DES }\end{array}$ \\
\hline
\end{tabular}

Sumber : LKP Kabupaten Bintan

Tabel. 4.5

Pagu dan Realisasi Dana Alokasi Umum Desa Berakit

\begin{tabular}{|l|l|l|l|l|}
\hline TAHUN & PAGU & REALISASI & PERSEN & SUM \\
\hline
\end{tabular}




\begin{tabular}{|c|c|c|c|c|}
\hline & & & TASE & BER4. \\
\hline 2016 & $\begin{array}{c}1.930 .054 . \\
646\end{array}$ & 1.933 .601 .841 & 102,11 & $\begin{array}{c}\text { DAU- } \\
\text { DES }\end{array}$ \\
\hline
\end{tabular}

Sumber : LKP Desa Berakit

\section{Mekanisme Penyaluran Dana Desa di Desa Berakit}

Setelah Menteri Keuangan menetapkan dan mengesahkan anggaran Dana Desa untuk tiap-tiap Kabupaten/ Kota di Indonesia, maka Bupati/ Walikota menetapkan alokasi dana desa untuk tiaptiap desa.

Bupati Bintan selaku Kepala Daerah Kabupaten Bintan telah menerbitkan Peraturan Bupati Bintan Nomor 17 Tahun 2015 tentang Tata cara Pembagian dan Penetapan Rincian Dana Desa Setiap Desa Kabupaten Bintan Tahun Anggaran 2016 Melalui Kepala desa Berakit.

Menurut peraturan tersebut dan hasil dari wawancara dengan aparat desa berakit mekanisme penyaluran dana desa di Desa Berakit Kabupaten Bintan dilaksanakan dalam beberapa tahap yaitu :

1. Tahap I pada bulan April sebesar Rp. $772.021 .858,4,-(40 \%)$ dari pagu dana desa berakit.

2. Tahap II pada bulan Agustus sebesar Rp. $772.021 .858,4,-(40 \%)$ dari pagu dana desa berakit.

3. Tahap III pada bulan Oktober sebesar Rp. $386.010 .929,2,-$ (20\%) dari pagu dana desa berakit.
Penyaluran Dana Desa tahap I dilakukan setelah Kepala Desa menyampaikan Anggaran Pendapatan dan Belanja Desa (APBDes) paling lambat bulan Maret dan laporan realisasi pengunaan dana desa semester sebelumnya.

5. Penyaluran Dana Desa tahap II dilakukan setelah Kepala Desa menyampaikan laporan realisasi penggunaan dana desa semester I.

Akan tetapi fakta dilapangan tidak sesuai dengan aturan yang telah ditetapkan. Hal ini berdasarkan data dan informasi yang penulis dapat bahwa Dana Desa tahap pertama di terima oleh Bendahara Umum Desa Berakit dari Pusat pada Bulan Mei 2016, sedangkan menurut aturan tahap pertama sudah harus diserahkan ke desa pada bulan April.

Pencairan Dana Desa ke desa di Kabupaten Bintan dan di teruskan ke desa berakit baru dilakukan pada bulan Juli hal ini disebabkan karena ada beberapa administrasi yang harus dilengkapi untuk proses pencairan seperti Surat Keputusan Bupati tentang penggunaan Dana Desa, penyusunan Rencana Kerja Anggaran Dana Desa di berakit dan kesiapan aparatur pemerintahan desa dalam mengajukan proses pencairan dana desa ujar kepala desa berakit atau seperti alur dibawah ini : 


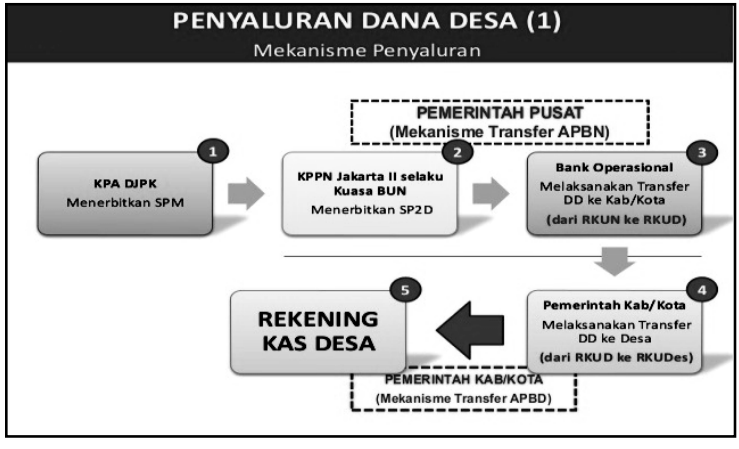

Secara umum penyeluran Dana Desa (DD) telah berjalan dengan baik. Namun demikian pelaksanaan penyaluran DD di Desa Berakit masih terdapat kendala.Hal tersebut dapat diketahui melalui berbagai fenomena yang penulis temukan selama melaksanakan penelitian.

\section{Pencairan Dana Desa}

Sesuai ketentuan yang ditetapkan oleh Menteri Keuangan Nomor 93/PMK.07/2015 tentang Tata Cara Pengalokasian, Penyaluran, Penggunaan, Pemantauan, dan Evaluasi Dana Desa bahwa setelah dana desa tahap pertama disalurkan dari rekening umum Negara ke rekening umum daerah, maka Bendahara Umum Daerah selaku penerima dana desa dari pusat dapat melakukan pencairan dana desa ke masingmasing desa.

Dari hasil wawancara dengan aparat pemerintah setempat, mengatakan : Adapun proses pencairan dari Rekening Umum Daerah Kabupaten Bintan ke Rekening Umum Desa adalah sebagai berikut :

1. Kepala Desa melalui bendahara desa Surat Perintah Membayar (SPM) ke Dinas Pendapatan dan Pengelolaan Keuangan Kabupaten Bintan sesuai dengan Rencana Kerja Anggaan Dana Desa yang telah ditetapkan untuk tahap pertama. SPM yang diajukan harus mengatur pada peraturan yang berlaku baik dari segi format maupun lampiran dokumen yang dibutuhkan.

2. Setelah diverifikasi oleh Bagian Pembukuan dan Verifikasi Dinas Pendapatan dan Pengelolaan Keuangan Daerah Kabupaten Bintan, SPM yang diajukan diproses oleh Bagian Anggaran untuk kemudian diterbitkan Surat Perintah Pembayaran Dana (SP2D).

3. SP2D merupakan alat perintah pembayaran dari Bendahara Umum Daerah kepada bank persepsi untuk melakukan pembayaran atau pemindahbukuan dari Rekenning Umum Daerah Kabupaten Bintan ke Rekening Umum Desa.

Kendala yang dihadapi saat penyaluran dana desa yaitu pelaporan yang sedikit terlambat selesai di tahun sebelumnya sehingga menghabat pencairan di tahun sekarang ujar aparat desa berakit

\section{Pengelolaan Dana Desa}

Adapun pengelolaan dana desa yang dilakukan oleh aparat desa berakit, mereka mengatakan : Pengelolaan Dana Desa di desa Berakit Kabupaten Bintan sebagaimana undang-undang yang mengatur dikuasai penuh oleh Kepala Desa serta dibantu oleh Pelaksana Teknis Pengelolaan Keuangan Desa (PTPKD) yang merupakan unsur 
perangkat desa. Perangkat desa yang dimaksud adalah Sekretaris Desa, Kepala Seksi dan Bendahara Desa.

Berdasarkan wawancara Penulis dengan Kepala Bidang Anggaran Dinas Pendapatan dan Pengelolaan Keuangan Kabupaten Bintan bahwa dalam pengelolaan dana desa tugas dan tanggungjawab Kepala Desa dan Pelaksana Teknis Pengelolaan Keuangan Desa adalah sebagai berikut :

1. Kepala Desa, memiliki tugas sebagai berikut :

a. menetapkan kebijakan tentang pelaksanaan kegiatan yang bersumber dari Dana Desa

b. menetapkan Pelaksana Teknis Pengeloaan Kegiatan Dana Desa

c. menyetujui pengeluaran atas kegiatan yang bersumber dari dana desa

d. melakukan tindakan yang mengakibatkan pengeluaran atas dana desa

2. Sekretaris Desa, memiliki tugas atas pengelolaan dana desa sebagai berikut :

a. Menyusun dan melaksanakan kebijakan pengelolaan dana desa

b. melakukan pengendalian terhadap pelaksanaan kegiatan yang bersumber dari dana desa

c. menyusun pelaporan dan pertanggungjawaban pelaksanaan kegiatan yang bersumber dari dana desa

d. melakukan verifikasi terhadap buktibukti pengeluaran atas dana desa.
3. Kepala Seksi, memiliki tugas dan tanggungjawab terhadap pengelolaan dana desa sebagai berikut :

a. Menyusun Rencana Kegiatan Anggaran (RKA) dan rencana pelasanaan kegiatan yang menjadi tanggungjawabnya

b. melaksanakan kegiatan yang bersumber dari dana desa bersama Lembaga Kemasyarakatan Desa

c. mengendalikan pelaksanaan kegiatan

d. Melakukan tindakan pengeluaran atas kegiatan yang bersumber dari dana desa

e. melaporkan perkembangan pelaksanaan kegiatan kepada Kepala Desa

f. menyiapkan dokumen anggaran atas beban pengeluaran pelaksanaan kegiatan.

4. Bendahara Pengeluaran

Bendahara pengeluaran Dana Desa harus dijabat oleh staf urusan keuangan yang mempunyai tugas menerima, menyimpan, menyetorkan/membayarkan, menatausaha kan dan mempertanggungjawabkan pengeluaran atas Dana Desa.

Pengelolaan Keuangan Desa adalah keseluruhan kegiatan yang meliputi perencanaan, pelaksanaan, penatausahaan, pelaporan, dan pertanggungjawaban keuangan desa.Penyelenggaraan kewenangan Desa berdasarkan hak asal usul dan kewenangan lokal berskala Desa didanai oleh APBDesa. Penyelenggaraan 
kewenangan lokal berskala Desa selain didanai oleh APBDesa, juga dapat didanai oleh anggaran pendapatan dan belanja negara dan anggaran pendapatan dan belanja daerah.

Penyelenggaraan kewenangan Desa yang ditugaskan oleh Pemerintah didanai oleh anggaran pendapatan dan belanja negara. Dana anggaran pendapatan dan belanja negara dialokasikan pada bagian anggaran kementerian/lembaga dan disalurkan melalui satuan kerja perangkat daerah kabupaten/kota. Penyelenggaraan kewenangan Desa yang ditugaskan oleh pemerintah daerah didanai oleh anggaran pendapatan dan belanja daerah.

\section{Penggunaan Dana Desa}

Menurut kepala desa berakit dari hasil wawancara, dalam menggunakan Dana Desa berdasarkan empat prioritas penggunaan yaitu :

1. Pelaksanaan Pembangunan Desa

Penggunaan Dana Desa di desa Berakit untuk Pelaksanaan pembangunan desa ini dijabarkan menjadi beberapa kegiatan antara lain :

a. Pembangunan dan Perawatan Bangunan seperti bangunan posyandu, gedung PKK, gedung PAUD, balai desa, rumah ibadah dan lain-lain

b. Pembuatan Saran Kagiatan Olahraga dan Sosial seperti Lapangan Voli, Lapangan Sepak Bola, Poskamling dan lain-lain c. Semenisasi Jalan dan Lingkungan, paving blok, batu miring dan lain-lain

2. Pemberdayaan Masyarakat Desa

Penggunaan dana desa untuk kegiatan pemberdayaan masyarakat antara lain :

a. Pengadaan seragam untuk majlis taklim, dasawisma, posyandu, poskamling

b. Belanja Makan dan Minum kegiatan Posyandu, kegiatan PKK, pengadaan mesin potong rumput, terpal dan tenda untuk rukun warga

c. Pengadaan bibit, pupuk dan alat pertanian untuk masyarakat

d. Pengadaan mebeulir, genset, tong sampah dan lain-lain

e. Belanja atau pengadaan lain yang bermanfaat untuk pemberdayaan masyarakat

3. Penyelenggaraan Pemerintahan Desa Penggunaan Dana Desa untuk kegiatan Penyelenggaraan Pemerintahan Desa antara lain untuk pembelian meja kerja, kursi kerja dan lemari arsip.

4. Pembinaan Kemasyarakatan

Dana yang digunakan untuk kegiatan Pembinaan Kemasyarakatan dari Dana Desa berakit antara lain adalah untuk :

a. Pembelian peralatan olah raga dan kesenian untuk organisasi masyarakat desa

b. Pembelian barang pecah belah untuk PKK

c. Lain-lain kegiatan yang berhubungan dengan Pembinaan Kemasyarakatan 
Tabel. 4.

Realisasi Penggunaan Dana Desa Berakit menurut Prioritas

Tahun Anggaran 2016

\begin{tabular}{|l|l|l|l|}
\hline No & Prioritas Kegiatan & $\begin{array}{c}\text { Realisasi } \\
(\text { Rp. })\end{array}$ & Persen \\
\hline 1 & $\begin{array}{l}\text { Pelaksanaan } \\
\text { Pembangunan Desa }\end{array}$ & $\begin{array}{l}747.487 .80 \\
5.97\end{array}$ & 38.70 \\
\hline 2 & $\begin{array}{l}\text { Pemberdayaan } \\
\text { Masyarakat Desa }\end{array}$ & $\begin{array}{l}445.819 .89 \\
6.00\end{array}$ & 23.05 \\
\hline 3 & $\begin{array}{l}\text { Penyelenggaraan } \\
\text { Pemerintahan }\end{array}$ & $\begin{array}{l}639.264 .47 \\
7.00\end{array}$ & 33.10 \\
\hline 4 & $\begin{array}{l}\text { Pembinaan } \\
\text { Kemasyarakatan }\end{array}$ & 153.146 .08 & 7.01 \\
\hline
\end{tabular}

Sumber : LKP Desa Berakit

\section{Pertanggungjawaban Dana Desa}

Dari Hasil Wawancara, Kepala desa Berakit mengatakan : Setiap pengeluaran belanja atas Dana Desa harus didukung atau dilengkapi dengan bukti yang lengkap dan sah. Tanpa bukti yang lengkap dan sah, penggunaan dana desa tidak dapat dipertanggungjawabkan. Setiap aparatur pemerintahan desa yang terlibat dan bertanggungjawab atas penggunaan Dana Desa harus melengkapi dokumen pendukung, dokumen dimaksud diantaranya berupa : kuitansi pembelian, nota pembelian, dokumen pelaksanaan kegiatan, daftar hadir, daftar penerima dana, alat dan lain-lain untuk pihak ketiga.

Di Desa Berakit Kabupaten Bintan, pertanggungjawaban dana desa melekat pada Kepala Desa dan Pelaksana Teknis Pengelolaan Keuangan Desa (PTPKD). Bentuk pertanggungjawaban penggunaan Dana Desa oleh PTPKD adalah sebagai berikut :
1. Kepala Desa bertanggungjawab menyampaikan Laporan Penggunaan dan Realisasi Dana Desa ke Bupati Bintan yang dikoordinir oleh camat masingmasing. Penyampaian laporan realisasi penggunaan dana desa dilakukan dengan ketentuan semester I paling lambat minggu keempat bulan Juli dan semester II paling lambat minggu kedua bulan Januari tahun berikutnya.

2. Sekretaris bertanggungjawab membuat laporan Penggunaan Anggaran dan Realisasi kegiatan yang berkaitan dengan Dana Desa serta mengesahkan bukti pengeluaran dana desa.

3. Kepala Seksi bertanggungjawab membuat laporan kegiatan yang berada dalam tanggungjawab masing-masing serta melengkapi dokumen pendukung atas belanja dana desa yang digunakan.

4. Bendahara bertanggungjawab membuat pembukuan penggunaan Dana Desa seperti, Buku Kas Umum, Buku Kas Tunai, Buku Kas Bank dan buku lain yang diperlukan untuk sebuah laporan.

Selain aparat pemerintahan desa, masyarakat juga mempunyai tanggungjawab moral terhadappenggunaan dana desa yang bisa diwujudkan dengan menjaga fasilitas umum yang dibiayai dengan dana desa, serta mengawasi kegiatan serta penggunaan dana desa. Adapun alur pelaporanya sebagai berikut : 


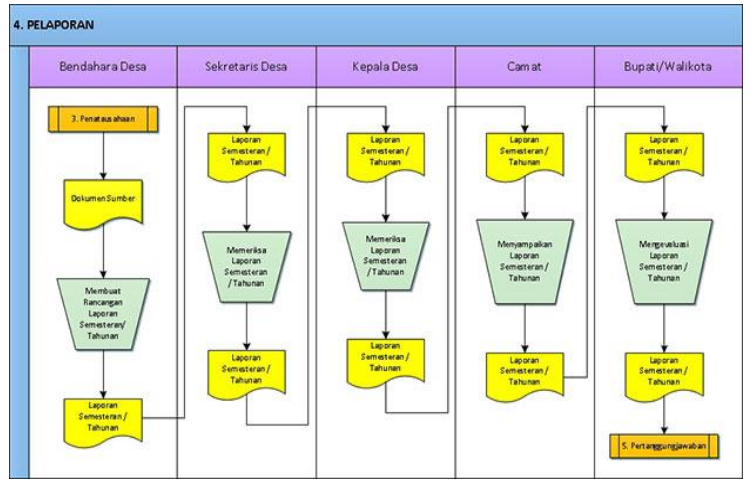

\section{PENUTUP}

\section{Simpulan}

Berdasarkan uraian hasil penelitian dan pembahasan yang telah diuraikan pada bab sebelumnya, maka dalam penulisan tesis ini dapat ditarik kesimpulan sebagai berikut

1. Penyaluran Dana Desa (DD) di Kabupaten Bintan berjalan cukup lancar. Hal ini dapat terlihat dari tahap persiapan serapan anggaran DD dan ADD di Kabupaten Bintan mencapaiSerapan Dana Desa sebesar 84\% dan Alokasi Dana Desa sebesar 96\%, dengan ratarata serapan $90 \%$;

2. Adapun kendala pelaksanaan Dana Desa Tahun 2016 adalah sebagai berikut

a) Pelaksanaan pilkades serentak tahun 2016 , yang baru dilantik tgl 2 Juni 2016 berdampak keterlambatan pertanggungjawaban SPJ tahap 1.

b) Penggantian perangkat desa oleh kepala desa definitif.

c) Transisi dinas yang menangani urusan pemerintahan dan pemberdayaan masyarakat desa ( 3 skpd kepada 1 bidang di BPMPKB) d) Kemampuan aparatur desa dalam menggunakan aplikasi siskeudes masih terbatas.

e) Perubahan regulasi dana desa belum dipahami secara menyeluruh.

f) Status pendamping desa terjadi kekosongan sejak april - september 2016 ( di tingkat pada kecamatan dan tenaga ahli kabupaten )

\section{Saran}

Berdasarkan kesimpulan dari hasil penelitian yang telah dikemukakan di atas, maka dapat diberikan saran-saran yang nantinya diharapkan dapat memperbaiki ataupun menyempurnakan pelaksanaan DD di Kabupaten Bintan masa datang. Saransaran dimaksud adalah :

1. Sosialisasi terhadap kebijakan Dana Desa diberikan kepada masyarakat luas sehingga setelah memahami kebijakan Dana Desa dan masyarakat juga akan lebih mudah untuk diajak berpartisipasi dalam pelaksanaan, ikut melestarikan hasil pelaksanaan Dana Desa serta ikut mengawasi jalannya Dana Desa.

2. Para pelaksana Dana Desa diberikan peningkatan pengetahuan melalui pendidikan dan latihan, khususnya yang menyangkut pengelolaan keuangan desa. Sedangkan untuk mempercepat pembuatan SPJ dan laporan pelaksanaan Dana Desa serta mengurangi kesalahan dalam pembuatan dokumen, perlu dibangunnya sistem aplikasi komputer 
yang memungkinkan akurasi dan kecepatan data.

\section{DAFTAR PUSTAKA}

Abdul Halim. 2007. Akuntansi Sektor Publik Akuntansi Keuangan Daerah. Jakarta. Salemba Empat

Abdul Sarif. 2011. Skripsi Pelaksanaan Alokasi Dana Desa di Desa Rambah Hilir Kecamatan Rambah Hilir Kabupaten Rokan Hulu

Abd. Rachim AF. 2015. Barometer Keuangan Negara. Yogyakarta. CV. Andi Offset

Afan Alfian. 2011. Mekanisme Kerja.http://pdipm-lamongan.

blogspot.co.id/ 2011/07/mekanismekerja-ipm.html

Agn. Supriyanto. 2015. Tata Kelola Koperasi Kredit atau Koperasi Simpan Pinjam. Yogyakarta. CV. Andi Offset

Ali Muhidin, Sambas dan Maman Abdurahman. 2007. Analisis Korelasi, Regresi, dan Jalur dalam Penelitian, Bandung : CV Pustaka Setia

Akbar Kaelola. 2009. Kamus Istilah Politik Kontemporer, Yogyakarta

Arikunto, S. Jabar, C. 2010. Evaluasi Program Pendidikan. Jakarta. Bumi Aksara

Ayuningtyas Suciani Utari. 2016. http://www.kompasiana.com/ ayuningtyassuciani/tata-kelola-alokasidana-desa-yang-tepat-sasaran-untukkepentingan-pembangunanmasyarakat_5692b102b47a61cc0dfbbf9 d. Jakarta. Kompas

Bagja Waluya. 2007. Sosiologi Menyelami Fenomena dalam Masyarakat. Bandung. PT. Setia Purnama Inves.
Dimyati dan Mudjiono. 2006.Belajar dan Pembelajaran.Jakarta. PT. Rineka Cipta

Eeng Ahman, Epi Indriani. 2007. Membina Kompetensi Ekonomi. Bandung. Grafindo Media Pratama

Eko Sujatmiko. 2014. Kamus IPS. Surakarta. Aksara Sinergi Media Cetakan I

Hanif Nurcholis. 2007. Teori dan Praktik Pemerintahan dan Otonomi Daerah. Jakarta. Grasindo

Hazeline Ayoeb. 2008. Forever Rich Mengelola Uang Banyak Bertambah Banyak. Jakarta. Mizan Publika

Hernold Ferry Makawimbang. 2016. Kompilasi Peraturan Perundangundangan Tentang Desa Sistem Pengelolaan dan Tanggungjawab Dana Desa. Jakarta. Libri

Herry Bertus.2007. Kaya di Dunia dan Masuk Surga.Jakarta. PT. Gramedia Pustaka Utama

http://kkbi.web.id/mekanisme. 2016

Indra Bastian.2007. Akuntansi Yayasan dan Lembaga Publik.Jakarta. Erlangga 2007. Akuntansi Sektor Publik. Jakarta. Erlangga

Irwan Gani dan Siti Amalia. 2015. Alat Analisis Data(Aplikasi statistic untuk penentuan bidang Ekonomi dan Sosial. Yogyakarta. CV. Andi Offset

James A. Hall, 2007. Sistem Informasi Akuntansi. Jakarta. Salemba Empat

Jazim Hamidi dan Mustafa Lutfi. 2010. Civic Edication Antara Realitas Politik dan Implementasi hukumnya. Jakarta. Gramedia

Jonny Purba. 2006. Pengelolaan Lingkungan Sosial. Jakarta. Yayasan Obor Indonesia 
Kuntowijoyo. 2008. Paradigma Islam Interpretasi untuk Aksi. Bandung. PT. Mizan Pustaka

Kumorotomo, Wahyudi. 2008. Akuntabilitas Birokrasi Publik. Yogyakarta. Pustaka Pelajar

Nurliana. 2009. Skripsi Pengelolaan Alokasi Dana Desa Dalam Pembangunan Fisik di Desa Sukomulyo Kecamatan Sepaku Kabupaten Penajam Paser Utara

Saifuddin. 2014. Pengelolaan Pembelajaran Teoritis dan Praktis. Yogyakarta. Penerbit Deepublish

Sukmadinata. 2006. Metode Penelitian Pendidikan. Bandung. Remaja Rosdakarya

Tim Visi Yustisia. 2015. Undang-Undang Nomor 6 Tahun 2015 tentang Desa dan Peraturan Terkait. Jakarta. Visi Media

Totok Gunawan dkk. 2007. Fakta dan Konsep Geografi.Jakarta. Inter Plus 